\title{
Metabolite Profiling of Black Rice (Oryza sativa L.) Following Xanthomonas oryzae pv. oryzae Infection
}

\author{
Ema Nur Hidayah ${ }^{1}$, Febri Adi Susanto ${ }^{2,3}$, Tri Joko ${ }^{2,4}$, Yekti Asih Purwestri ${ }^{1,2}$, \\ Tri Rini Nuringtyas ${ }^{1,2, *}$, Manar Fayiz Mousa Atoum ${ }^{5,6}$, and Asad $\mathrm{Jan}^{7}$ \\ ${ }^{1}$ Department of Tropical Biology, Faculty of Biology, Universitas Gadjah Mada Jl. Teknika Selatan, Sekip Utara, Yogyakarta 55281, \\ Indonesia; ${ }^{2}$ Research Center for Biotechnology, Universitas Gadjah Mada;Jl. Teknika Utara, Depok, Sleman, Yogyakarta 55281, \\ Indonesia; ${ }^{3}$ Department of Biochemistry Molecular Biology \& Molecular Plant Sciences, Michigan State University, East Lancing, MI \\ 48824, USA; ${ }^{4}$ Department of Crop Protection, Faculty of Agriculture, Universitas Gadjah Mada;Jl. Flora, Bulaksumur, Yogyakarta 55281, \\ Indonesia; ${ }^{5}$ Molecular Biology and Genetics, The Hashemite University, PO Box 330127, 13133 Zarqa, Jordan; ${ }^{6}$ Department of Medical \\ Laboratory Sciences, The Hashemite University, Zarqa, Jordan; ${ }^{7}$ Institute of Biotechnology \& Genetic Engineering, \\ University of Agriculture Pesthawar, 25130, Khyber Pakhtunkhwa, Pakistan
}

Received: May, 10, 2021; Revised: Sep, 25, 2021; Accepted Oct, 22, 2021

\begin{abstract}
Black rice as a functional food contains a high anthocyanin content, which functions as an antioxidant. However, bacterial leaf blight (BLB) caused by Xanthomonas oryzae pv. oryzae (Хoo) has resulted in a reduction in yield. Black rice has been reported to have a higher resistance to BLB than white rice cultivars. This study aimed to determine the metabolite responses of two black rice cultivars, 'Melik' and 'Pari Ireng', compared to two white rice cultivars, 'IR64' and 'Java14', after infection with Xoo pathotype IV and mock negative control. Gas Chromatography-Mass Spectrometer (GC-MS) was used for the metabolite profiling analysis, followed by the quantification of total phenolic concentration (TPC) and total flavonoid concentration (TFC). Across all cultivars, the results revealed that following Xoo infection, there were significantly higher concentrations of primary metabolites including sugars, sugar alcohols, fatty acids, glycerol, and some organic acids. In 'Pari Ireng' and 'Melik' cultivars, sugars including fructose, and gluco-hexodialdose were significantly higher than the white cultivars following the infection. The infection significantly increased the TPC of all cultivars. 'Java 14' contained the highest TPC while 'Pari Ireng' was observed as cultivars with the highest TFC. These results suggested that pigmented rice cultivars possess a different chemical defense strategy from the white ones to respond to Xoo infection.
\end{abstract}

Keywords: Bacterial leaf blight, Disease resistance, Functional food, GC-MS, Improvements rice production, Metabolomics, Pigmented rice, Xoo infection

\section{Introduction}

Rice (Oryza sativa L.) is one of the most important staple foods of many Asian countries such as China, India, Bangladesh, Vietnam, the Philippines, and Indonesia. Statistical data indicate that the global consumption of rice from 2016 to 2017 was an average of $54.24 \mathrm{~kg}$ per capita. After China and India, Indonesia had the third-highest rice consumption of more than $50 \times 10^{6} \mathrm{t}$ over this period (Shahbandeh, 2019). The increasing rice consumption in Indonesia is related to the increasing population. However, this increase in population has not been reflected in the overall rice production, resulting in increasing rice demand (Pratiwi and Purwestri, 2017).

Rice farmers aim to meet the rising demand through improvements in the rice production process (Hameed et al., 2021). However, biotic and abiotic factors have caused many problems, with one of them being bacterial leaf blight (BLB) in rice caused by Xanthomonas oryzae pv. oryzae (Xoo). The symptoms of BLB can present early in the seedling phase to maturity (Tasliah, 2012). Xoo has many pathotypes (i.e. strains) and is characterized by rapid changes, making its control difficult (Sudir et al., 2013; Susanto and Sudir, 2012). The BLB infestation from April to September 2018 was estimated at approximately 23055 ha, making this disease the third most devastating pest after rats and rice stem borers (Direktorat Perlindungan Tanaman Pangan, 2018). Almost all rice cultivation areas in Indonesia have experienced some levels of infection.

One of the strategies to manage BLB is planting rice varieties resistant to the pathotypes. The use of diseaseresistant rice cultivars is the most economical way to combat the disease. Black rice is one of the pigmented rice types that have exhibited resistance against a range of biotic and abiotic stresses. Its consumption has begun as a functional food, i.e. food that naturally or through addition contains one or more compounds considered to possess health benefits owing to its high anthocyanin content which serves as a natural antioxidant (Kristamtini et al., 2014; Pratiwi and Purwestri, 2017). As a monocot, rice has been commonly used as a model organism to study defense responses in cereal crops. An integrated molecular approach combining transcriptomics, proteomics, and metabolomics is needed to study the response of rice plants to environmental changes (Ahuja et al., 2010).

\footnotetext{
*Corresponding author e-mail: tririni@ugm.ac.id.
} 
Metabolites in the plant are strongly influenced by the genes present and genetic modifications. The environment also has significant effects on metabolic changes (Brunetti et al., 2013). Plants adapt to the changes in the environmental conditions by producing inducible metabolites or by increasing the levels of existing metabolites that may serve as stress signals or defense (Schwachtje et al., 2019).

Plants often apply multi strategies to defend themselves from both biotic and abiotic attacks. Pigmented rice is preferable due to its high anthocyanin content. Wijaya et al. (2017) suggested that black pigmented rice adjusts its metabolism to produce high anthocyanin content compared to the white and red ones. Accumulative information also showed that pigmented rice tends to have a higher resistance to Xoo infection (Sutrisno et al., 2018) with the support of phenylalanine ammonia lyase (PAL) (Solekha et al., 2020).

Metabolite profiling has been used as a novel tool for the comparative display of gene function. This tool not only has the potential to provide deeper insights into the complex regulatory processes of metabolite production but can also be used for direct determination of the resulting phenotype (Kumar et al., 2017; Pan et al., 2013). In this study, the objective was to observe and evaluate the metabolic changes in pigmented rice following infection by Xoo. This information may provide a better understanding of plant defenses in pigmented and white rice information crucial for improvement in rice production.

\section{Materials and Methods}

The rice seeds used in this study included two local black rice cultivars 'Pari Ireng' and 'Melik' obtained from Balai Pengkajian Teknologi Pertanian - BPTP (Institute for Agricultural Technology) Yogyakarta. The white cultivar 'Java14' was used as a resistant control (Susanto and Sudir, 2012), whereas 'IR64' cultivar was used as a susceptible control. These were obtained from Balai Besar Penelitian Tanaman Padi Sukamandi - BBPadi (Indonesian Center for Rice Research - ICRC), Subang, West Java (Sudir et al., 2013). The Xoo isolate used was pathotype IV with a concentration of $10^{8}$ colony-forming units originally from BBPadi, Subang, West Java. The inoculum was cultured in a peptone sucrose agar medium in Petri dishes. Inoculation of plants with the $X o o$ via the leaf clipping method was performed in the late afternoon to avoid the time of the day experiencing high heat and high evaporation (Sutrisno et al., 2018). The negative treatments, called as mock, were done by clipping the leaves with aquadest only. Both mock and infected plants were cultivated for $4 \mathrm{~d}$ in the greenhouse. At the end of the treatment, leaves were harvested for chemical analysis.

\subsection{Metabolite profiling using Gas}

\section{Chromatography-Mass Spectrometer (GC-MS)}

For metabolite profiling, rice leaf samples were collected from the plants $4 \mathrm{~d}$ following inoculation (Narsai et al., 2013). For each treatment, approximately $50 \mathrm{mg}$ of the leaf material was deep-frozen at $-80{ }^{\circ} \mathrm{C}$ prior to extraction. The leaf samples were refined using liquid nitrogen and then extracted by adding $1 \mathrm{~mL}$ of an extraction buffer (isopropanol: acetonitrile: water, 3:3:2, previously cooled at $-20{ }^{\circ} \mathrm{C}$ ) to the leaf material. The supernatant was stored at $-20^{\circ} \mathrm{C}$ for $30 \mathrm{~min}$ to $40 \mathrm{~min}$ prior to vacuuming using a cold vacuum pump and then treated by adding $10 \mu \mathrm{L}$ methoxyamine hydrochloride solution (20 mg mL $\mathrm{m}^{-1}$ ). The derivatization process was performed by adding $90 \mu \mathrm{L}$ MSTFA at $37^{\circ} \mathrm{C}$ for 30 min (Sana et al., 2010). The samples were allowed to stand at room temperature for $2 \mathrm{hr}$ prior to injection into a GC-MS and stored in a freezer for further analysis.

The analysis was performed using a GC-MS mass selective detector and Rxi-5MS capillary column $(30 \mathrm{~m} \times$ $0.25 \mathrm{~mm}$; layer thickness of $0.25 \mu \mathrm{m}$ ). Helium was used as the carrier gas at a constant rate of $1 \mathrm{~mL} \mathrm{~min}^{-1}$, and $1 \mu \mathrm{L}$ of the gas was injected (split ratio 10:1). The temperature of the injected gas was set at $310{ }^{\circ} \mathrm{C}$, of the column at $80^{\circ} \mathrm{C}$, and the ion at $250^{\circ} \mathrm{C}$. The temperature regime was initiated from isothermal at $80{ }^{\circ} \mathrm{C}$ (5 min), and the temperature increase was set at $10{ }^{\circ} \mathrm{C} \mathrm{min}^{-1}$ until the final temperature of $330^{\circ} \mathrm{C}$ was reached (43 min). GC-MS was performed on each leaf sample using three replications.

\subsection{Sample Preparation for Total Phenolic \\ Concentration (TPC) and Total Flavonoid \\ Concentration (TFC) Quantification}

Extracts were prepared by homogenizing $50 \mathrm{mg}$ fresh leaves sample with $4 \mathrm{~mL}$ phosphate buffer $(\mathrm{pH}$ 6.5; $0.1 \mathrm{M})$, followed by centrifugation at $10000 \mathrm{rpm}(1 \mathrm{rpm}=$ $1 / 60 \mathrm{~Hz}$ ) for $15 \mathrm{~min}$ at $2{ }^{\circ} \mathrm{C}$. Next, $2 \mathrm{~mL}$ of absolute ethanol was added to $2 \mathrm{~mL}$ of supernatant and boiled in water at $98{ }^{\circ} \mathrm{C}$ for $30 \mathrm{~min}$. Subsequently, $5 \mathrm{~mL}$ of distilled water was added to the sample, and the solution was slowly mixed. The samples were divided into two equal parts to measure TPC and TFC.

\subsubsection{Total Phenolic Content (TPC)}

Analysis of TPC was conducted by spectrophotometry using the Folin-Ciocalteu method (Everette et al., 2010) with some modifications. Amount $1 \mathrm{~mL}$ of a sample was added to $0.5 \mathrm{~mL}$ Folin-Ciocalteau reagent (1:1) along with $1 \mathrm{~mL} \mathrm{Na}{ }_{2} \mathrm{CO}_{3}(7.5 \%)$ and $2.5 \mathrm{~mL}$ of distilled water. The sample was incubated for $1 \mathrm{~h}$ prior to measuring the absorbance at $650 \mathrm{~nm}$ (Dahima et al., 2014). Gallic acid was used as a standard for the calibration curve at a concentration of $10 \mu \mathrm{g} \mathrm{mL}^{-1}$ to $160 \mu \mathrm{g} \mathrm{mL}^{-1}$ in the standard curves with intervals of $20 \mu \mathrm{g} \mathrm{mL} \mathrm{mL}^{-1}$. TPC was calculated in terms of gallic acid equivalents.

\subsubsection{Total Flavonoid Content (TFC)}

A colorimetric test with aluminum chloride was used to measure TFC. Amount $1 \mathrm{~mL}$ of a sample was added to $0.5 \mathrm{~mL}$ of $2 \% \mathrm{AlCl}_{3}$ and $2.5 \mathrm{~mL}$ distilled water. Then, the samples were briefly shuffled and incubated for $10 \mathrm{~min}$ at $37{ }^{\circ} \mathrm{C}$ prior to measuring the absorbance at $425 \mathrm{~nm}$ (Pekal and Pyrynska, 2014). Quercetin was used as the standard. The quercetin concentration used in the standard curve was ranging from (20 to 100) $\mu \mathrm{M} \mathrm{mL}^{-1}[(20,40,60,80$ and 100) $\left.\mu \mathrm{M} \mathrm{mL}^{-1}\right]$. The determination of TFC was calculated in terms of equivalent quercetin in reference to the standard curve.

\subsection{Data and Statistical Analysis}

Metabolites were determined based on the spectrum similarity of each sample peak to the examples in the mass spectrometry library (i.e., NIST and WILEY). MS results reflected compounds derivatized using silylation. 
Compounds identification was validated by checking all detected metabolites with NIST (webbook.nist.gov). Visualization of the entire area of the metabolite distribution was performed using Heat Map in Microsoft Excel 2010. The statistical analyses for metabolites levels, TPC, and TFC were performed using ANOVA with significance set at the $5 \%$ confidence level, followed by post hoc Duncan's multiple ranges in SPSS Statistics 24 (Adinurani, 2016).

\section{Results and Discussion}

\subsection{Metabolite profiling}

GC-MS based metabolomics was used for metabolite profiling of black rice following Xоo infection. Eleven primary metabolites were detected in the metabolite profile of rice leaves. Metabolites found in all cultivars were mostly primary metabolites, including sugars, alcoholic sugars, fatty acids, glycerol, and some organic acids with different concentrations in each cultivar and treatment (Figure 1). These metabolites were previously reported present in the rice leaves detected using GC-MS (Kusano et al., 2015).

In the mock plants, the white cultivars showed higher sucrose levels and gluco-hexodialdose than the black cultivars. The higher mannitol level around 5 to 8 times was only observed on the IR64 cultivars but not the 'Java14'. The rest of the metabolites were comparable among all cultivars. Interesting shifting of metabolites profiles was observed after the plants were treated with Хоo (Figure 1).

A

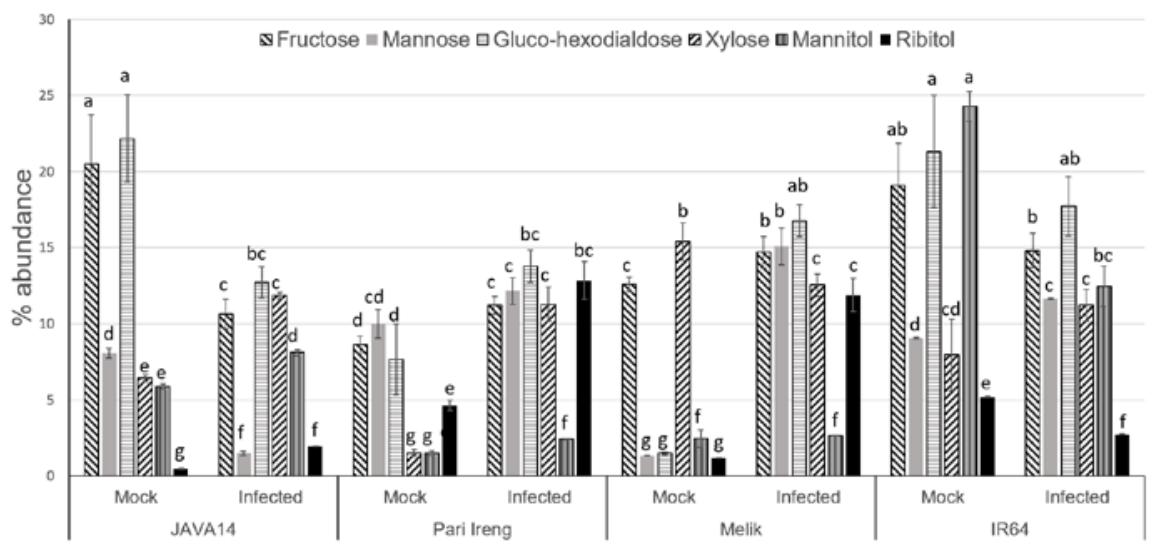

B

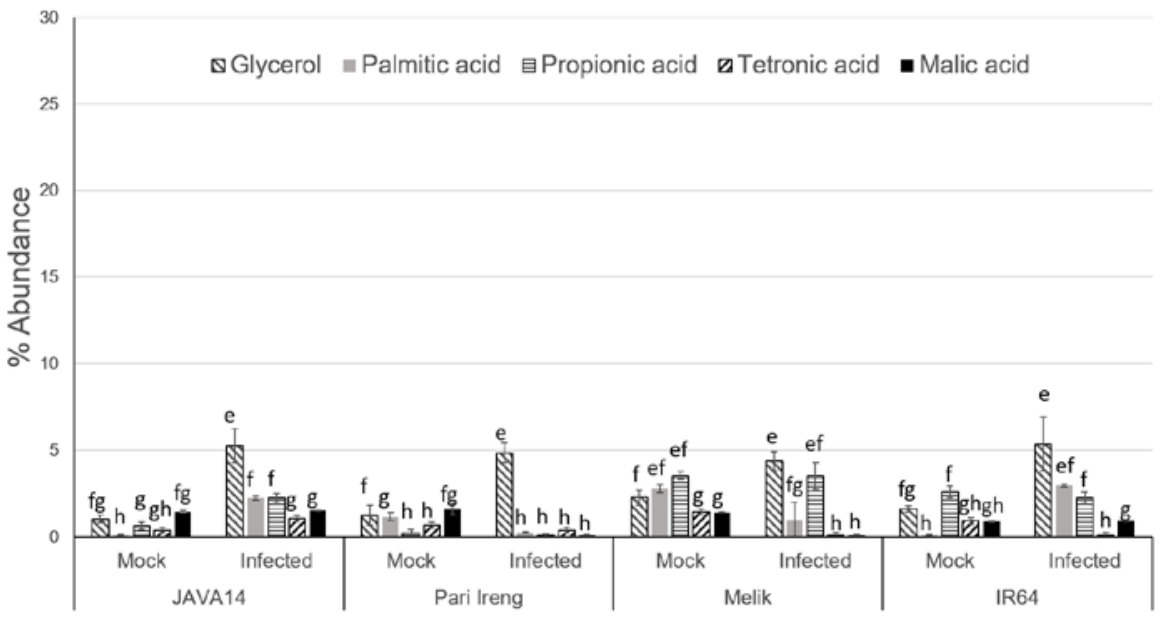

Figure 1. Metabolite contents of four rice cultivars following infection with Xanthomonas oryzae. A. Sugars and sugar alcohols, B. Lipids and organic acid. Data present the average and standard error of three replicates each. Different letters denote significant differences at $* P<0.05$ analyzed using ANOVA.

The heat map of the metabolite profile revealed that metabolite profiles of all cultivars changed after infection (Figure 2). It can be observed from the change of color of several metabolites such as fructose, palmitic acid, glycerol, ribitol, and xylose in the heat map. Several responses were different between the white rice (i.e., 'Java14' and 'IR64') with pigmented rice (i.e. 'Pari Ireng' and 'Melik'). However, a similar pattern was observed in glycerol after infection. In all cultivars, increased glycerol levels were consistently observed. Fructose and glucohexodialdose levels were found to be higher in 'Pari Ireng' and 'Melik' following Xоo infection than those following the mock treatment. In contrast, the levels decreased in the white rice cultivars 'Java14' and IR64 compared with the levels in control. Sugars as a resource of carbon were also reported to be depleted in the leaves' surface upon bacterial infection (Bezrutczyk et al., 2018). In addition, alcoholic sugars such as mannitol demonstrated a different pattern. 
Mannitol level decreased in 'IR64' following the Xoo infection but increased in 'Java14', 'Melik', and 'Pari Ireng'. The low content of mannitol in IR64 as the representative of susceptible cultivars suggested the role of this sugar alcohol in defense against disease. The correlation of mannitol to bacterial infection remains unclear. However, it was reported to function as antimicrobials recently (Nguyen et al., 2019).

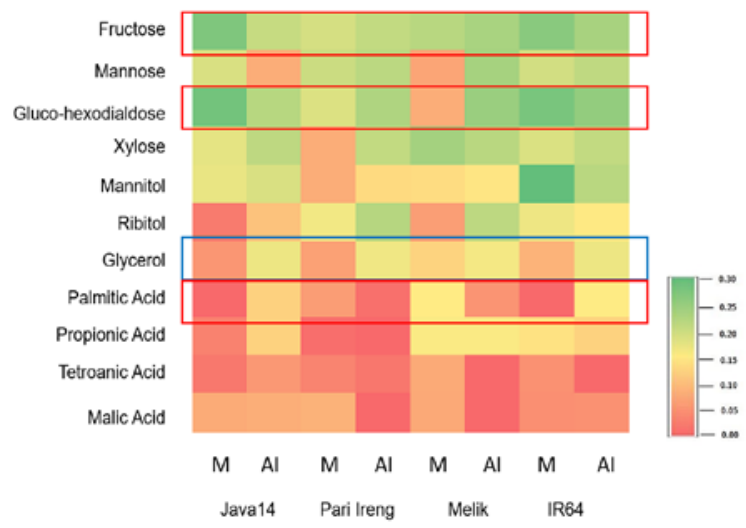

Figure 2. Heat map of metabolite profile on four rice cultivars following Xoo infection. M: Mock, AI: after infection. The red box indicates the different response of pigmented rice cultivars than the white cultivars. The blue box indicates the metabolites changed after infection observed in all cultivars.

The opposite response was observed for palmitic acid. A higher level of palmitic acid was observed in 'Java14' and 'IR64', while in 'Pari Ireng' and 'Melik' were lower. A group of sugars was found in all tested cultivars: xylose, glycerol, mannitol, and mannose. Glycerol levels increased across all cultivars following the infection. Remarkably, mannose levels in 'IR64', 'Melik', and 'Pari Ireng' increased following Xоo infection but decreased in 'Java14'. A decreased concentration of malic acid following the infection was observed only in the black rice cultivars, 'Melik' and 'Pari Ireng'. Malic acid is known to play a role in regulating $\mathrm{pH}$ and osmotic homeostasis in plants with pathogen infection (Figure 1.).

Sugars have been recognized as important signaling molecules that affect a variety of physiological responses. They regulate the expression of genes involved in photosynthesis, metabolism, and defense responses (Bolouri-Moghaddam et al., 2010; Morkunas and Ratajczak, 2014). Fructose and gluco-hexodialdose levels increased in the black rice cultivars following Xoo infection than the control treatment, whereas they decreased in the white rice cultivars.

Xoo infection tends to decrease sugar production and, subsequently, the energy to produce metabolites in defense response. In particular, most plant pathogens actively penetrate the plant cell wall to access the intracellular nutrients, whereas plants subsequently, strengthen cell walls and secrete antimicrobial components into the cell wall in an attempt to stop pathogen invasion as a defensive response (Malinovsky et al., 2014). Several studies have shown that sugar transportation plays an essential role in the rice defense response against pathogens (Chen et al., 2010a, 2010b, 2012; Julius et al., 2017). Accumulation of sucrose and gluco-hexodialdose in plants following Xoo infection triggers the allocation of nutrients and signals for the activation of the defense response. Remarkably, another sugar, xylose, was found in all tested cultivars. Increased xylose level in 'Java14' and 'Pari Ireng' following Xoo infection may trigger a defensive response against pathogens. Another compound found in the metabolite profile based on the GC-MS analysis seems to play a role against the pathogen. However, the pattern obtained by spectroscopy suggests that the compound is unlikely to be a major compound that serves in the defense mechanism. The roles of the compounds present in plants are listed in Figure 1. These are considered to play a role in the defense mechanism but not as major signaling compounds.

Metabolite profiling of black rice following Xoo infection demonstrated that there were more kinds of sugars than other metabolites. Xoo-infected rice may continue to experience changes in metabolite composition and sugar content that can affect PR protein formation and induce plant defenses (Sun et al., 2013). The result of metabolite profiling can be used to determine the metabolite responses and defense strategies plants use in response to BLB.

\subsection{TPC following Xoo infection}

Phenol, a family of compounds involved in plant defense, is considered important in plant metabolism. The TPC values of four rice cultivars were $0.45 \%$ to $0.98 \%$ $(\mathrm{w} / \mathrm{w})$, within the range value commonly available in grain-producing plants. The phenolic compounds in plants are usually associated with the tolerance characters against both biotic and abiotic stress due to the natural antioxidants property of phenolics (Vrancheva et al., 2020). 'Java 14' had the highest TPC than the other cultivars in each treatment, followed by the black rice cultivars, and 'IR64' (Figure 3). The increase in TPC indicated that there is a plant response that was a defense mechanism in response to the presence of the pathogen. 'IR64' had the lowest TPC; thus, this finding supported the fact that 'IR64' is highly susceptible to the Xoo pathotype (Khaeruni et al., 2014; Sudir et al., 2013). The role of phenolic compounds in the plant defense against Xoo has been reported by Khan et al. (2014) and FanRei (2017). High TPC was significantly detected in the resistant rice cultivars, i.e. 'Basmati-385' and 'Basmati-2000' (Khan et al., 2014). More recent study using a library of phenolics compounds showed that 10 out of 45 phenolic compounds had been proven to inhibit the Xanthomonas oryzae pv. oryzae (Xoo) type III. Moreover, these ten compounds can also suppress the hypersensitive response (HR) caused by Xoo in tobacco (Fan et al., 2017). 


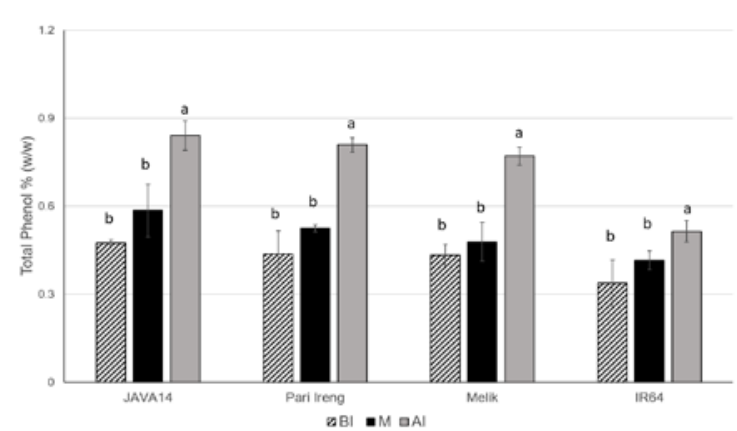

Figure 3. Total phenol content of four cultivars rice leaves after Xoo infection. BI: before infection, M: Mock, AI: after infection *** $P \leq 0.0001$. Alphabets above histograms showed significant differences between treatments in the same cultivar based on ANOVA with a $5 \%$ confidence level.

\subsection{TFC following Xoo infection}

The highest TFC following Xoo infection was observed in the black rice cultivars. In contrast, low TFC was observed across all treatments in the white rice cultivars. Notably, the black rice showed differences in terms of TFC between the negative control and pathogen treatment groups (Figure 4). The presence of pathogens can trigger an increase in the production of flavonoids as a defense response in plants.

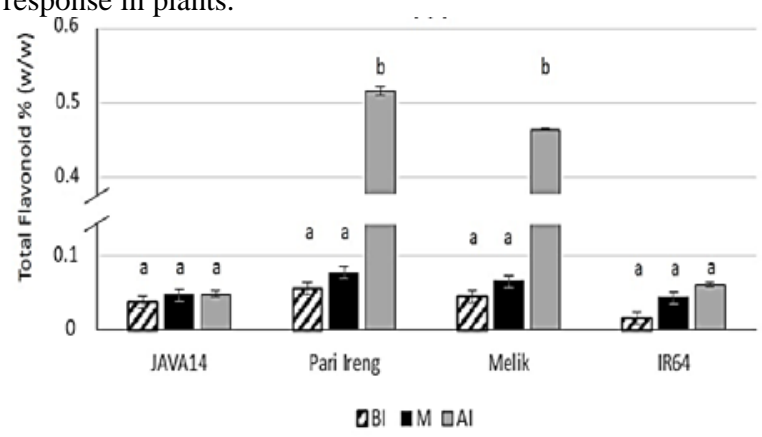

Figure 4. Total flavonoid content of four cultivars rice leaves after Xoo infection. BI: before infection, M: Mock, AI: after infection *** $P \leq 0.0001$. Alphabets above histograms showed significant differences between treatment in the same cultivar based on ANOVA with a $5 \%$ confidence level

Pigmented rice cultivars differ from white ones because of their high anthocyanin content in their aleuron layer. Therefore, metabolism in pigmented rice is different from white rice; hence, it might affect the response of the plants to bacterial infections. In this study, the authors observed how the black rice cultivars ('Melik' and 'Pari Ireng') showed a different metabolite profile following the Xoo infection.

To better understand the chemical defenses utilized by black rice against $\mathrm{Xoo}$, TPC and TFC were evaluated on all rice cultivars. The increase in TPC in 'Pari Ireng', 'Melik', and 'IR64' indicated the presence of a defensive response against pathogen infection. However, the phenolic compounds alone seem to be ineffective against Xoo. The black rice cultivars also showed increases in TPC following Xoo infection and showed similar responses against pathogen infection. This result is in line with a study by Solekha et al. (2020) that reported a significant increase in the phenylalanine ammonia-lyase (PAL) activity in 'Pari Ireng' and 'Melik' after Xoo infection. This indicated the active shikimate pathway leading to the synthesis of both phenolic and flavonoids compounds. Furthermore, specific phenolic metabolites have been investigated i.e. o-coumaric acid (OCA) and trans-3indoleacrylic acid, for their inhibition activities against Xoo. The OCA specifically showed its activity on the early steps of defense by inhibiting the HR progression by Xoo, while the trans-3-indoleacrylic acid was proven for its high antibacterial action (Fan et al., 2017). Further study of the significant phenolic and flavonoid compounds present in the black rice against Xoo infection may become interesting.

Based on the results, the authors found that 'Pari Ireng' has higher TPC and TFC than 'Melik', specifying a stronger defensive response in 'Pari Ireng' than in 'Melik'. Differences in terms of disease intensity observed during the second week in the black rice cultivars showed that a new main defense mechanism was activated after a week following the infection. Thus, within the first week, there were no differences in terms of the disease intensity values (data not shown). The combination of relatively high TFC, TPC, and fatty acid content in 'Java14' suggests that these compounds reduce disease intensity unlike in the other cultivars. Although TPC of 'Java14' was lower than that of the black rice cultivars, the TPC produced was believed to be more effective against BLB infection. This pattern was similar in the black rice cultivars.

\section{Conclusion}

The metabolite profiling of two pigmented rice cultivars and two white cultivars in response to Xoo infection detected primary metabolites including sugars, sugar alcohols, fatty acids, glycerol, and some organic acids observed in all cultivars following Xoo infection. An increase of glycerol levels was observed in all cultivars after infection. In pigmented rice, 'Melik' and 'Pari Ireng', sugars including fructose and gluco-hexodialdose were higher in concentration following Xoo infection. The infection significantly increased the TPC of all cultivars. 'Java14' contained the highest TPC while 'Pari Ireng' was observed as cultivars with the highest TFC. It can be concluded that pigmented rice cultivars possess a different in chemical defence strategy from the white ones to respond to Xoo infection.

\section{Acknowledgment}

This research was supported by PUPT Competitive Research Grant 2016, The Ministry of Research, Technology, and Higher Education Indonesia to YAP contract number 863/UN1-P.III/LT/DIT-LIT/2016. This study is part of a master's thesis research by Ema Nur Hidayah. The authors thank Ir. Sudir from Balai Besar Penelitian Tanaman Padi, Sukamandi, Subang, West Java for the valuable suggestions on the Xoo pathotype IV infection.

\section{References}

Adinurani, P.G. 2016. Design and analysis of agro trial data: Manual and SPSS. Plantaxia, Yogyakarta, Indonesia

Ahuja I, de Vos, RC, Bones AM and Hall RD. 2010. Plant molecular stress responses face climate change. Trends Plant Sci., 15(12): 664-674. 
Bolouri-Moghaddam MR, Roy KL, Xiang L, Rolland F and Van den Ende W. 2010. Sugar signaling and antioxidant network connections in plant cells. FEBS J., 277: 2022-2037.

Brunetti C, George RM, Tattini M, Field K and Davey MP. 2013. Metabolomics in plant environmental physiology. J. Exp. Bot., 64(13): 4011-4020.

Bezrutczyk M, Yang J, Eom J S, Prior M, Sosso D, Hartwig T, and Yang B. 2018. Sugar flux and signaling in plant-microbe interactions. Plant J., 93(4): 675-685.

Chen F, Gao MJ, Miao YS, Yuan YX, Wang MY, Li Q, Mao BZ, Jiang LW and He ZH. 2010a. Plasma membrane localization and potential endocytosis of constitutively expressed Xa21 proteins in transgenic rice. Mol. Plant., 3(5): 917-926.

Chen LQ, Hou BH, Lalonde S, Takanaga H, Hartung ML, Qu XQ, Guo WJ, Kim JG, Underwood W, Chaudhuri B, Chermak D, Antony G, White FF, Sommerville SC, Mudgett MB, Frommer WB. 2010b. Sugar transporters for intercellular exchange and nutrition of pathogens. Nature., 468: 527-532.

Chen LQ, Qu XQ, Hou BH, Sosso D, Osorio S, Fernie AR, Frommer WB. 2012. Sucrose efflux mediated by SWEET proteins as a key step for phloem transport. Science., 335: 207-211.

Dahima V, Sharma SS, Khokar MK, Hooda KS. 2014. Postinfectional biochemical changes in maize leaves affected by banded leaf and sheath blight disease. Indian Phytopath., 67(4): 370-373.

Direktorat Perlindungan Tanaman Pangan. 2018. Estimation of major pest attacks on planting period of 2018 according to each province of Indonesia

Everette JD, Bryant QM, Green AM, Abbey YA, Wangila GW and Walker RB. 2010. Thorough study of reactivity of various compound classes toward the Folin-Ciocalteu reagent. J. Agric. Food Chem., 58(14): 8139-8144.

Fan S, Tian F, Li J, Hutchins W, Chen H, Yang F, Yuan X, Cui Z, Yang $\mathrm{CH}$, and He C. 2017. Identification of phenolic compounds that suppress the virulence of Xanthomonas oryzae on rice via the type III secretion system. Mol. Plant. Pathol., 18(4): 555-568

Hameed, A., Padda I.U.H. and Salam A. 2021. Analysis of food and nutrition security in Pakistan: A contribution to zero hunger policies Sarhad J. Agric., 37(3): 1025-1042.

Julius BT, Leach KA, Tran TM, Mertz RA, and Braun DM. 2017. Sugar transporters in plants: new insights and discoveries. Plant Cell Physiol., 58: 1442-1460.

Khaeruni A, Taufik M, Wijauanto T and Johan EA. 2014. Development of bacterial leaf blight disease inoculated on three varieties of paddy rice at various growth stage. J. Fitopatologi Indonesia., 10(4):119-125.

Khan JA, Afroz S, Arshad HMI, Sarwar N, Anwar HS, Saleem K, Babar MM and Jamil FF. 2014. Biochemical basis of resistance in rice against Bacterial leaf blight disease caused by Xanthomonas oryzae pv. Oryzae. Adv. Life Sci., 1(3): 181-190

Kristamtini K, Taryono, Basunanda P and Murti RH. 2014. Lokal genetic variability of rice pericarp color parameters and total anthocyanine content of eleven local black rice and their correlation. Ilmu Pertanian, 17(1): 57-70.

Kumar R, Bohra A, Pandey AK, Pandey MK, Kumar A. 2017. Metabolomics for plant improvement: Status and prospects. Front. Plant Sci., 8(1302): 1-27.

Kusano M, Yang Z, Okazaki Y, Nakabayashi R, Fukushima A and Saito K. 2015. Using metabolomic approaches to explore chemical diversity in rice. Mol. Plant., 8(1): 58-67.

Malinovsky FG, Fangel JU and Willats WGT. 2014. The role of the cell wall in plant immunity. Front. Plant Sci., 5(178): 1-12.

Morkunas I, and Ratajczak L. 2014. The role of sugar signaling in plant defense responses against fungal pathogens. Acta Physiol. Plantarum., 36:1607-1619.
Narsai R, Wang C, Chen J, Wu J, Shou H and Whelan J. 2013. Antagonistic, overlapping and distinct responses to biotic stress in rice (Oryza sativa) and interactions with abiotic stress. BMC Genomics., 14(93): 1-21.

Nguyen T, Kim T, Ta HM, Ye WS, Choi J, Mizar P and Kim KK. 2019. Targeting mannitol metabolism as an alternative antimicrobial strategy based on the structure-function study of mannitol-1-phosphate dehydrogenase in Staphylococcus aureus. MBio., 10(4- e02660-18): 1-23.

Pan Q, Dai Y, Nuringtyas TR, Mustafa NR, Schulte AE, Verpoorte R and Choi YH. 2014. Investigation of the chemomarkers correlated with flower colour in different organs of Catharanthus roseus using NMR-based metabolomics. Phytochem. Anal., 25(1): 66-74.

Pękal A and Pyrzynska K. 2014. Evaluation of aluminium complexation reaction for flavonoid content assay. Food Anal. Methods., 7:1776-1782.

Pratiwi R and Purwestri YA. 2017. Black rice as a functional food in Indonesia. Functional Foods in Health and Disease. 7(3):182194.

Sana TR, Steve F, Wohlgemuth G, Kratekar A, Jung K and Ronald PC. 2010. Metabolomic and transcriptomic analysis of the rice response to the bacterial blight pathogen Xanthomonas oryzae pv. oryzae. Metabolomics., 6: 451-465.

Schwachtje J, Whitcomb SJ, Firmino AAP, Zuther E, Hincha DK and Kopka J. 2019. Induced, imprinted and primed metabolic responses of plants to changing environments: Does metabolism store and process information? Front. Plant Sci., 10(106): 1-13.

Shahbandeh M. 2019. Global rice consumpion 2018/2019, by country (in 1,000 metric tons).

(https://www.statista.com/statistics/255971/top-countries-basedon-rice-consumption-2012-2013/\#statisticContainer)

Solekha R, Susanto FA, Joko T, Nuringtyas TR, Purwestri YA. 2020. Phenylalanine ammonia lyase (PAL) contributes to the resistance of black rice against Xanthomonas oryzae pv. oryzae. . J. Plant Pathol., 102: 359-365.

Sutrisno, Susanto FA, Wijayanti P, Retnoningrum M D, Nuringtyas TR, Joko T, Purwestri Y A. 2018. Screening of resistant Indonesian black rice cultivars against bacterial leaf blight. Euphytica., 214 (199): 1-12.

Sudir S, Yogi YA. 2013. Composition and patotype distribution of Xanthomonas oryzae pv. oryzae in rice central production in South Sumatera. Jurnal Penelitian Pertanian Tanaman Pangan. 32(2): 98-108.

Sun L, Yang DL, Kong Y, Chen Y, Li XZ, Zeng LJ, Li Q, Wang $\mathrm{E}$ and He ZH. 2014. Sugar homeostasis mediated by cell wall invertase grain in complete filling 1 (GIF1) plays a role in preexisting and induced defense in rice. Mol. Plant Pathol., 15(2): 161-173.

Susanto U and Sudir. 2012. Rice genotype resistance against Xanthomonas oryzae pv. oryzae patotype III, IV, dan VIII. .Penelitian Pertanian Tanaman Pangan, 31(2): 108-116.

Tasliah. 2012. Resistance gene on rice to bacterial leaf blight caused by Xanthomonas oryzae pv. oryzae. Jurnal Penelitian dan Pengembangan Pertanian, 31(3): 103-112.

Underwood W. 2012. The plant cell wall: A dynamic barrier against pathogen invasion. Front. Plant Sci., 3(85): 1-6.

Vrancheva R, Popova A, Mihaylova D and Kratanov A. 2020. Phytochemical analysis, in vitro antioxidant activity and germination capability of selected grains and seeds. Jordan J Biol Sci., 13(3): 337-342

Wijaya DN, Susanto FA, Purwestri YA, Ismoyowati D, Nuringtyas TR. 2017. NMR metabolite comparison of local pigmented rice in Yogyakarta. Indones. J. Biotechnol., 22(2): 6875. 